\title{
Patterns and regulation of ribosomal RNA transcription in Borrelia burgdorferi
}

\author{
Julia V Bugrysheva ${ }^{1}$, Henry P Godfrey ${ }^{2}$, Ira Schwartz ${ }^{1}$, Felipe C Cabello ${ }^{1 *}$
}

\begin{abstract}
Background: Borrelia burgdorferi contains one $16 \mathrm{~S}$ and two tandem sets of 23S-5S ribosomal (r) RNA genes whose patterns of transcription and regulation are unknown but are likely to be critical for survival and persistence in its hosts.

Results: RT-PCR of B. burgdorferi N40 and B31 revealed three rRNA region transcripts: $16 \mathrm{~S}$ rRNA-alanine transfer RNA (tRNA ${ }^{\text {Ala }}$ ); tRNA ${ }^{\text {lle; }}$; and both sets of $23 \mathrm{~S}-5 \mathrm{~S}$ rRNA. At $34^{\circ} \mathrm{C}$, there were no differences in growth rate or in accumulation of total protein, DNA and RNA in B31 cultured in Barbour-Stoenner-Kelly (BSK)-H whether rabbit serum was present or not. At $23^{\circ} \mathrm{C}, \mathrm{B} 31$ grew more slowly in serum-containing BSK-H than at $34^{\circ} \mathrm{C}$. DNA per cell was higher in cells in exponential as compared to stationary phase at either temperature; protein per cell was similar at both temperatures in both phases. Similar amounts of rRNA were produced in exponential phase at both temperatures, and rRNA was down-regulated in stationary phase at either temperature. Interestingly, a rel $I_{B b u}$ deletion mutant unable to generate (p)ppGpp did not down-regulate rRNA at transition to stationary phase in serum-containing $\mathrm{BSK}-\mathrm{H}$ at $34^{\circ} \mathrm{C}$, similar to the relaxed phenotype of $E$. coli relA mutants.
\end{abstract}

Conclusions: We conclude that rRNA transcription in B. burgdorferi is complex and regulated both by growth phase and by the stringent response but not by temperature-modulated growth rate.

\section{Background}

Borrelia burgdorferi, the cause of Lyme disease, is maintained in nature in a sylvatic cycle that includes its arthropod host, Ixodes scapularis, and mammals such as deer and rodents $[1,2]$. The ability of B. burgdorferi to cycle successfully between different hosts, survive for prolonged periods of starvation in flat ticks and proliferate rapidly to reach sufficiently high numbers inside ticks taking a blood meal to permit transmission to mammals $[1,3]$ suggests that $B$. burgdorferi may display novel and finely tuned mechanisms to regulate its growth in response to nutrient composition and other environmental cues [4-7]. Analysis of the genome of this bacterium, however, reveals a relative paucity of genes encoding regulatory molecules, suggesting that $B$. burgdorferi might control gene expression by ancillary methods such as growth rate-dependent control and the stringent response [8-10].

\footnotetext{
* Correspondence: cabello@nymc.edu

'Department of Microbiology and Immunology, Basic Science Building, New York Medical College, Valhalla, NY 10595, USA

Full list of author information is available at the end of the article
}

It is generally accepted that the nutritional quality of the environment acting through changes in bacterial growth rate regulates ribosome biosynthesis and ribosome availability. This regulation results in changes in ribosomal RNA (rRNA) concentration. rRNA molecules are thus the major factor regulating synthesis of ribosomes in Escherichia coli [11] and other prokaryotic and eukaryotic microorganisms [12]. E. coli has seven operons encoding rRNA genes; each operon contains genes for all three rRNA species which are transcribed as a single transcript and then processed into 16S, $23 \mathrm{~S}$ and 5S rRNA [11,13]. This organization permits synthesis of equimolar amounts of each rRNA species. In E. coli, rRNA synthesis involves the transcription factor DksA [14]. It is negatively regulated by (p)ppGpp (guanosine3'-diphosphate-5'-triphosphate and guanosine-3', 5'-bisphosphate, collectively), a global regulator involved in bacterial adaptation to many environmental stresses, and positively regulated by the concentration of the initiating nucleoside triphosphates acting in trans on the P1 and P2 rRNA promoters [13]. The other major mechanism to control rRNA synthesis in E. coli is
Ciomed Central

(C) 2011 Bugrysheva et al; licensee BioMed Central Ltd. This is an Open Access article distributed under the terms of the Creative Commons Attribution License (http://creativecommons.org/licenses/by/2.0), which permits unrestricted use, distribution, and reproduction in any medium, provided the original work is properly cited. 
growth rate-dependent control [11]. Under this (p) ppGpp-independent control mechanism, ribosome concentration in each cell is proportional to growth rate.

The B. burgdorferi chromosome contains a single $16 \mathrm{~S}$ rRNA gene and two tandem sets of $23 \mathrm{~S}$ and $5 \mathrm{~S}$ rRNA genes located at nt435201-446118, as well as genes encoding transfer tRNAs for alanine (tRNA ${ }^{\text {Ala }}$ ) and isoleucine (tRNA ${ }^{\text {Ile }}$ ) $[10,15,16]$ (Figure 1). All these genes except tRNA ${ }^{\text {Ile }}$ are present in the same orientation on the chromosome. Not only are patterns of transcription and regulation of rRNA genes uncharacterized in $B$. burgdorferi, but there is little information as to whether rRNA synthesis in this bacterium is regulated by the stringent response, by growth rate, or by some other mechanism. We previously found that B. burgdorferi N40 co-cultured with tick cells down-modulated its levels of (p)ppGpp and decreased $\mathrm{rel}_{B b u}$ expression while growing more slowly than in Barbour-StoennerKelly (BSK)-H medium [17]. This simultaneous decrease in (p)ppGpp and growth rate was associated with downmodulation of $16 \mathrm{~S}$ rRNA [18], and suggested that growth rate but not (p)ppGpp or the stringent response regulated rRNA levels in B. burgdorferi. A B. burgdorferi $297 \Delta r e l_{B b u}$ deletion mutant lost both the ability to synthesize (p)ppGpp and to reach stationary phase cell densities as high as those of its wild-type parent even though the parent and the mutant multiplied at similar rates during exponential phase of growth [19].

We have now examined both the organization of transcription of B. burgdorferi rRNA and the influence of growth phase and the stringent response on rRNA synthesis. This information is especially critical to improving our understanding of the ability of $B$. burgdorferi to shift between the rapid growth of acute mammalian and arthropod infection and slow growth during persistence in these hosts [3,20,21]. Although the incompletely defined nutritional requirements of $B$. burgdorferi prevented experimental determination of whether B. burgdorferi rRNA synthesis was regulated by growth rate at a single temperature, we found that rRNA transcription was regulated by growth phase and that $r l_{B b u}$ was required for down-regulation of rRNA at the entrance of B. burgdorferi to stationary phase.

\section{Results}

Transcription pattern of $B$. burgdorferi rRNA

RT-PCR analysis of the region coding for B. burgdorferi N40 rRNA using primers shown in Table 1 and Figure 1 demonstrated the presence of common transcripts (consistent with the expected $683 \mathrm{bp}$ amplicon, Table 1) for $16 \mathrm{~S}$ rRNA and tRNA ${ }^{\mathrm{Ala}}$. The common transcripts detected for 23S and 5S rRNA (1403 bp) and for 5S and 23S-rrlA (631 bp) show that the 23S-5S-23S-5S region is expressed as a single transcript (Figure $2 \mathrm{~A}$ ). tRNA $^{\text {Ile }}$ was transcribed independently of the upstream $16 \mathrm{~S}$ rRNA and the downstream 23S-5S rRNA transcript since no amplicons were obtained with primers designed to amplify tRNA ${ }^{\text {Ala }}$-tRNA ${ }^{\text {Ile }}$ and tRNA ${ }^{\text {Ile }}$-23S rRNA segments (Figure 1, Figure 2A). However, PCR with these primers amplified products of the expected size (781 bp

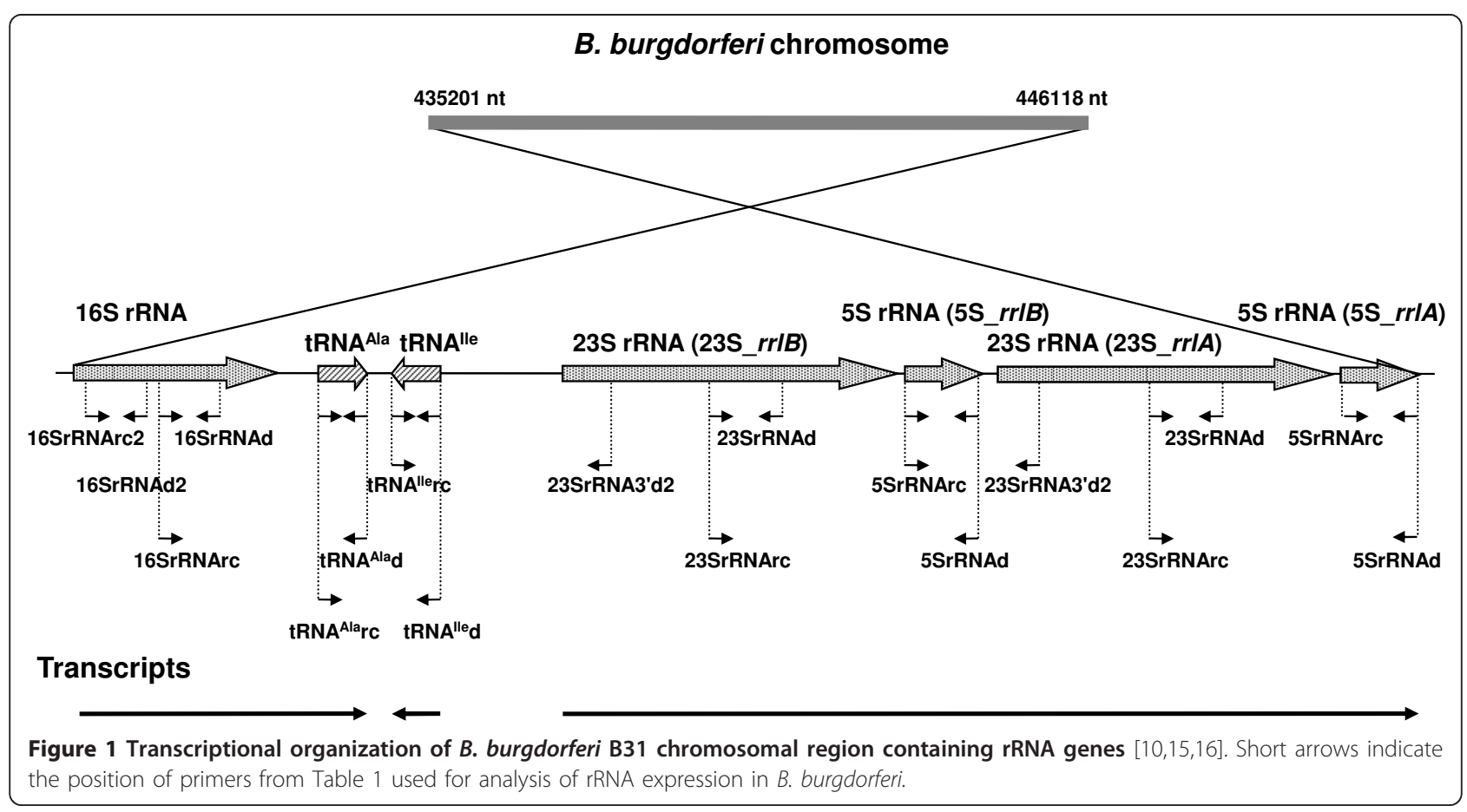


Table 1 Oligonucleotide primers used in this study

\begin{tabular}{|c|c|c|c|}
\hline Amplified gene/region & Primer Name & Sequence $\left(5^{\prime} \rightarrow 3^{\prime}\right)$ & Amplicon (bp) \\
\hline \multirow[t]{2}{*}{$5 S$ rRNA } & 5SrRNAd & CCCTGGCAATAACCTACTC & 112 \\
\hline & 5SrRNArc & CCCTGGTGGTTAAAGAAAAG & \\
\hline \multirow[t]{4}{*}{$16 \mathrm{~S}$ rRNA } & 16SrRNAd & GGCCCGAGAACGTATTCACC & 288 \\
\hline & 16SrRNArc & CGAGCGCAACCCTTGTTATC & \\
\hline & 16SrRNAd2 & GTTCCAGTGTGACCGTTCAC & 295 \\
\hline & 16SrRNArc2 & CTTAGAACTAACGCTGGCAG & \\
\hline \multirow[t]{2}{*}{$23 \mathrm{~S}$ rRNA } & 23SrRNAd & ССTCTTAACCTTCCAGCACC & 248 \\
\hline & 23SrRNArc & GGTTAGGCTATAAGGGACCG & \\
\hline \multirow[t]{2}{*}{ tRNA $A^{l l e}$} & tRNA ${ }^{l l e} d$ & GATCATAGCTCAGGTGGTTAG & 69 \\
\hline & tRNA ${ }^{1 \mathrm{le}} \mathrm{rc}$ & GACCAGGATGAGTTGAACATC & \\
\hline \multirow[t]{2}{*}{ tRNA $A^{\text {Ala }}$} & tRNA ${ }^{\text {Ala }} \mathrm{d}$ & GTTAAGGGACTCGAACCCTTG & 65 \\
\hline & tRNA ${ }^{\text {Ala }} \mathrm{rC}$ & GTTAGCTCAGTTGGCTAGAG & \\
\hline \multirow[t]{2}{*}{$f l a B$} & flaBd & TCATTGCCATTGCAGATTGTG & 278 \\
\hline & flaBrc & ACCTTCTCAAGGCGGAGTTAA & \\
\hline \multirow[t]{2}{*}{$16 \mathrm{~S}$ rRNA - tRNA ${ }^{\text {Ala }}$} & 16SrRNArc & CGAGCGCAACCCTTGTTATC & 683 \\
\hline & tRNA ${ }^{\text {Ala }} \mathrm{d}$ & GTTAAGGGACTCGAACCCTTG & \\
\hline \multirow[t]{2}{*}{ tRNA ${ }^{\text {Ala }}-t_{R N A^{l l e}}$} & $\mathrm{tRNA}^{\text {Ala }} \mathrm{rc}$ & GTITAGCTCAGTTGGCTAGAG & 781 \\
\hline & tRNA ${ }^{l l e} d$ & GATCATAGCTCAGGTGGTTAG & \\
\hline \multirow[t]{2}{*}{ tRNA ${ }^{l l e}-23 S$ rRNA } & tRNA ${ }^{l l e} \mathrm{re}_{\mathrm{C}}$ & GACCAGGATGAGTTGAACATC & 2522 \\
\hline & 23SrRNA3'd2 & CTTATTACAGACTAAGCCTAAACGTC & \\
\hline \multirow[t]{2}{*}{$23 S$ rRNA - $5 S$ rRNA } & 23SrRNArc & GGTTAGGCTATAAGGGACCG & 1403 \\
\hline & 5SrRNAd & CCCTGGCAATAACCTACTC & \\
\hline \multirow[t]{2}{*}{$5 S$ rRNA - $23 S$ rRNA } & 5SrRNArc & CCCTGGTGGTTAAAGAAAAG & 631 \\
\hline & 23SrRNA3'd2 & СTTATTACAGACTAAGCCTAAACGTC & \\
\hline
\end{tabular}

and 2522 bp, respectively) from genomic DNA (Figure 2B, Table 1). Transcripts consistent with expected sizes were also detected by RT-PCR for tRNA genes: tRNA $^{\text {Ala }}(65 \mathrm{bp})$ and tRNA ${ }^{\text {Ile }}(69 \mathrm{bp})$ as well as for the three different rRNA genes: 23S, 248 bp; 16S, 288 bp; 5S, 112 bp (Figure 2C). Identical results were obtained with B. burgdorferi B31 (data not shown). These results confirm the prediction that the rRNA containing region in $B$. burgdorferi is transcribed as three independent transcripts $[15,16]$.

\section{Growth rate of $B$. burgdorferi and synthesis of DNA, RNA} and protein under different conditions of nutrition and temperature

To identify the effect of growth rate and (p)ppGpp levels in $B$. burgdorferi, we examined growth and accumulation of DNA, RNA and protein in B. burgdorferi cultured at $34^{\circ} \mathrm{C}$ in BSK-H in the presence or absence of rabbit serum (an attempt at nutritional variation) and in B. burgdorferi cultured in BSK-H in the presence of rabbit serum at $34^{\circ} \mathrm{C}$ and $23^{\circ} \mathrm{C}$ (temperature variation). B. burgdorferi B31 was used for these experiments because the high cellular concentrations it reaches during in vitro culture $\left(>3 \times 10^{8}\right.$ cells $\left./ \mathrm{ml}\right)$ facilitated obtaining sufficient quantities of cells to permit measurement of DNA, RNA and protein by colorimetric assays
[22,23]. Because rRNA constitutes more than $80 \%$ of total cellular RNA [11], rRNA was estimated from measurements of total RNA.

At $34^{\circ} \mathrm{C}$, the growth rate of $B$. burgdorferi and synthesis of total DNA, RNA and protein were unaffected by the presence or absence of rabbit serum as spirochetes grew from $3 \times 10^{4}$ to $3 \times 10^{8}$ cells $/ \mathrm{ml}$ (Figure 3 ). Levels of RNA and protein per cell in B. burgdorferi were similar to those in slow-growing E. coli [8], while the level of DNA per cell was similar to that of normally dividing E. coli [8]. At $23^{\circ} \mathrm{C}$, there was a lag in increases in B. burgdorferi cell numbers and total DNA, RNA and protein; in addition growth rate was slower, final concentrations of cells were three times lower (Figure 3A), as were total DNA, RNA and protein relative to those at $34^{\circ} \mathrm{C}$ (Figure 3B-D). These differences did not appear to be due to triggering of the stringent response by these environmental variations, since similar amounts of (p) ppGpp were detected in B. burgdorferi B31 grown in $\mathrm{BSK}-\mathrm{H}$ in the presence or absence of rabbit serum at $34^{\circ} \mathrm{C}$ or in the presence of rabbit serum at $23^{\circ} \mathrm{C}$ (Figure $4)$. These results indicate that the absence of rabbit serum in BSK-H did not trigger slow growth at $34^{\circ} \mathrm{C}$ or changes in (p)ppGpp levels at either temperature.

For calculation of DNA, RNA and protein on a per cell basis, data from washed exponential and stationary 


\section{A. RT-PCR analysis of rRNA intragenic region}

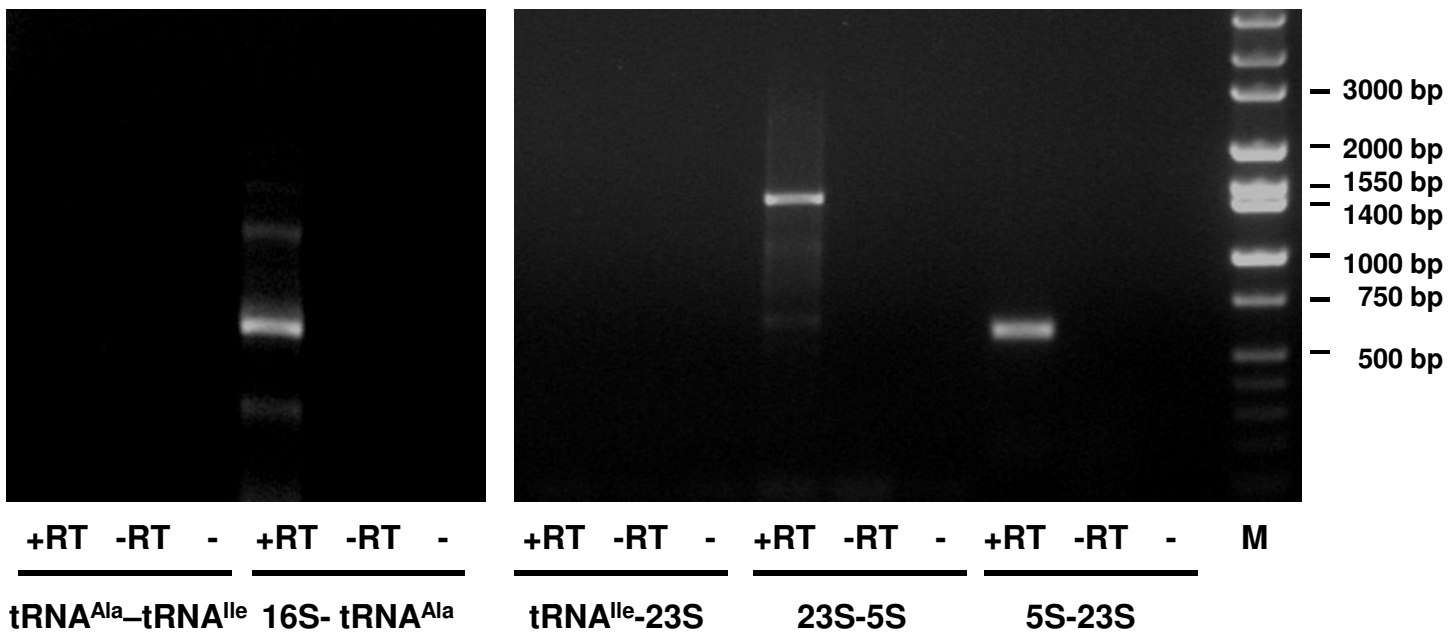

\section{B. PCR analysis of rRNA intragenic region}

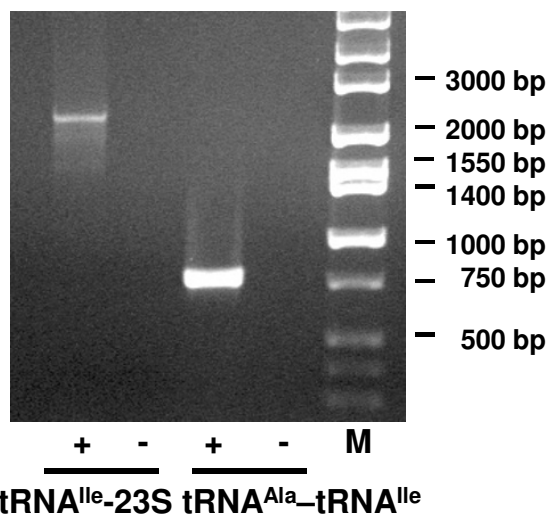

\section{RT-PCR analysis of rRNA gene expression}
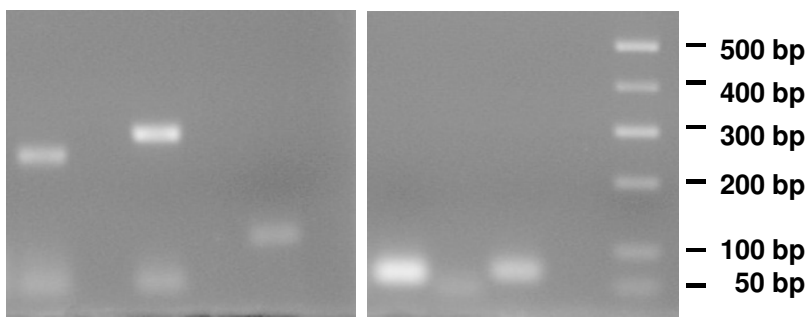

+RT -RT+RT-RT+RT-RT +RT-RT+RT-RT M

Figure 2 Analysis of $\boldsymbol{B}$. burgdorferi N40 rRNA gene transcription. A. RT-PCR analysis of rRNA intragenic regions. +RT, complete reaction; -RT, reaction without reverse transcriptase; -, reaction without RNA. B. PCR analysis of rRNA intragenic regions. +, complete reaction; -, reaction without DNA. C. RT-PCR analysis of rRNA gene expression. +RT, complete reaction; - RT, reaction without reverse transcriptase.

phase cells were analyzed separately (see legend to Figure 3 for details). Since we could not obtain sufficient amounts of material for analysis of exponential growth at $23^{\circ} \mathrm{C}$ because of the relative insensitivity of colorimetric assays and high costs of large volumes of BSK-H culture medium, only the data from day 11 were used for this condition. At $34^{\circ} \mathrm{C}$, there was significantly more DNA per cell in exponentially growing $B$. burgdorferi B31 cultures containing rabbit serum than at any of the other growth conditions $(\mathrm{P}<0.05$, one-way analysis of variance, Tukey-Kramer multiple comparison post-test) (Figure 3E). There was significantly less RNA per cell in stationary phase B. burgdorferi at $23^{\circ} \mathrm{C}$ than at $34^{\circ} \mathrm{C}$ (Figure $3 \mathrm{~F})(\mathrm{P}<0.05$, one-way analysis of variance, Tukey-Kramer multiple comparison post-test). There was no significant difference in protein per cell under any growth condition at any temperature (Figure 3G).
Because precise correlation between corresponding points on growth curves for cultures growing at different rates is difficult, it was therefore still unclear whether rRNA levels were regulated by growth rate or growth phase in B. burgdorferi B31.

\section{Effect of growth rate and stringent response on} accumulation of $16 \mathrm{~S}$ and $23 \mathrm{~S}$ rRNA in B. burgdorferi The apparent effect of growth rate on rRNA synthesis could be influenced by sampling B. burgdorferi that were in different growth phases at the two temperatures. Direct analysis of $16 \mathrm{~S}$ and $23 \mathrm{~S}$ rRNA levels in $B$. burgdorferi $\mathrm{B} 31$ grown in BSK-H containing serum at $34^{\circ} \mathrm{C}$ and $23^{\circ} \mathrm{C}$ revealed no difference in the levels of normalized $16 \mathrm{~S}$ rRNA expression in cells grown at different temperatures when the cells were at similar points in the growth phase (Figure 5A). Examination of rRNA in 


\section{Growth Phase}

\section{Exponential Stationary}

\section{A. Total cells}

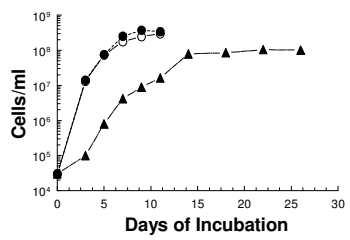

B. Total DNA

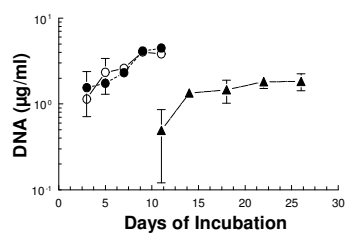

C. Total RNA

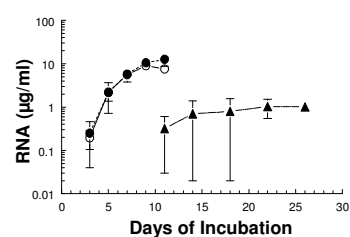

D. Total protein

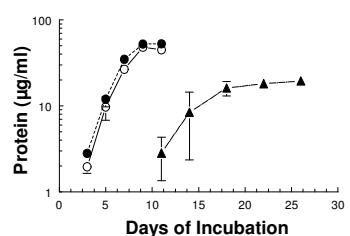

E. DNA per cell
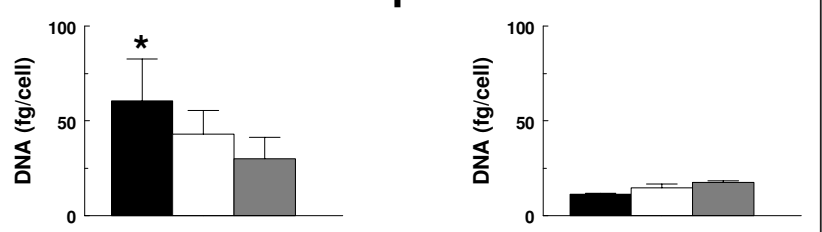

F. RNA per cell
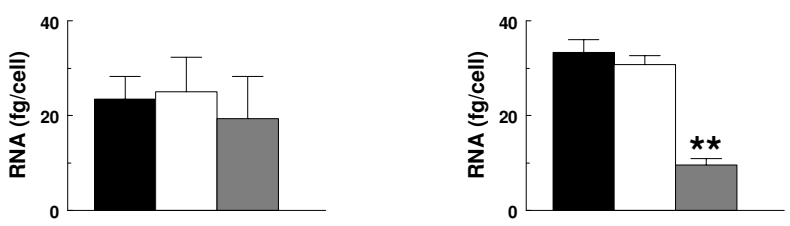

\section{G. Protein per cell}

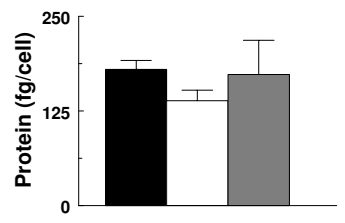

Figure 3 Cell growth (A), total DNA (B), total RNA (C) and total protein (D) (mean \pm SE) per $\mathrm{ml}$ in B. burgdorferi B31 cultured in BSK-H at $34^{\circ} \mathrm{C}$ in the presence (solid circle) or absence (open circle) of $6 \%$ rabbit serum, and in $\mathrm{BSK}-\mathrm{H}$ at $23^{\circ} \mathrm{C}$ in the presence of $6 \%$ of rabbit serum (triangle); Data point symbols obscure the error bars in some cases; Mean ( \pm SE) DNA (E), RNA (F) and protein (G) per $B$. burgdorferi $\mathrm{B} 31$ cell after culture in BSK-H containing $6 \%$ of rabbit serum at $34^{\circ} \mathrm{C}$ (black bar), in BSK-H containing no serum at $34^{\circ} \mathrm{C}$ (white bar), or in BSK-H containing $6 \%$ of rabbit serum at $23^{\circ} \mathrm{C}$ (gray bar). Data from pooled values from washed exponentially growing cells (days $3-5$ for the $34^{\circ} \mathrm{C}$ condition and day 11 for the $23^{\circ} \mathrm{C}$ condition) or washed stationary cells (days $7-11$ for the $34^{\circ} \mathrm{C}$ condition and days $14-26$ for the $23^{\circ} \mathrm{C}$ condition), and represent means of 4-8 values for DNA, RNA and protein from cells in exponential phase, and 12-18 values for cells in stationary phase. Data were analyzed by one-way analysis of variance with a Tukey-Kramer multiple comparisons post-test. *, DNA per cell was significantly greater $(P<0.05)$ in exponentially growing $B$. burgdorferi $B 31$ cultured at $34^{\circ} \mathrm{C}$ in the presence of $6 \%$ rabbit serum than in stationary phase $B$. burgdorferi under any culture condition examined. ${ }^{*}$, RNA per cell was significantly lower $(P<0.05)$ in stationary phase $B$. burgdorferi $\mathrm{B} 31$ cultured at $23^{\circ} \mathrm{C}$ in the presence of $6 \%$ rabbit serum than in $B$. burgdorferi cultured at $34^{\circ} \mathrm{C}$ in the presence or absence of $6 \%$ rabbit serum.

the $23^{\circ} \mathrm{C}$ culture was begun at lower cell concentrations since this culture reached stationary phase at about 3 -fold lower cell densities than cultures grown at $34^{\circ} \mathrm{C}$ (Figure 3A). Even though the average doubling time for B. burgdorferi $\mathrm{B} 31$ was $5 \mathrm{~h}$ at $34^{\circ} \mathrm{C}$ and $15 \mathrm{~h}$ at $23^{\circ} \mathrm{C}$ (Figure 3A), rRNA levels decreased significantly under both culture conditions with entry into stationary phase $(\mathrm{P}<0.05$, one-way analysis of variance, Tukey-Kramer multiple comparison post-test). A similar result was observed with $23 \mathrm{~S}$ rRNA (Figure 5B). These results indicate that the apparent down-regulation of total RNA per cell in cultures grown at $23^{\circ} \mathrm{C}$ compared to cultures grown at $34^{\circ} \mathrm{C}$ (Figures $3 \mathrm{C}, \mathrm{F}, 5 \mathrm{AB}$ ) was in fact due to comparing cells that had spent a longer time in stationary phase at $23^{\circ} \mathrm{C}$ than those growing at $34^{\circ} \mathrm{C}$, and was not the result of the decreased growth rate at the lower temperature.

To examine if the stringent response regulated rRNA levels in this bacterium, B. burgdorferi 297 and its $\Delta r e l_{B b u}$ derivative that could not synthesize (p)ppGpp were used [19]. Both strains multiplied at a similar rate in exponential phase in BSK-H at $34^{\circ} \mathrm{C}$ (Figure 6A) but the deletion mutant stopped dividing after day four of culture while densities of the wild-type strain continued to increase (Figure 6A). In wild-type B. burgdorferi, 16S and $23 \mathrm{~S}$ rRNA levels were very similar at 2 to 4 days of 


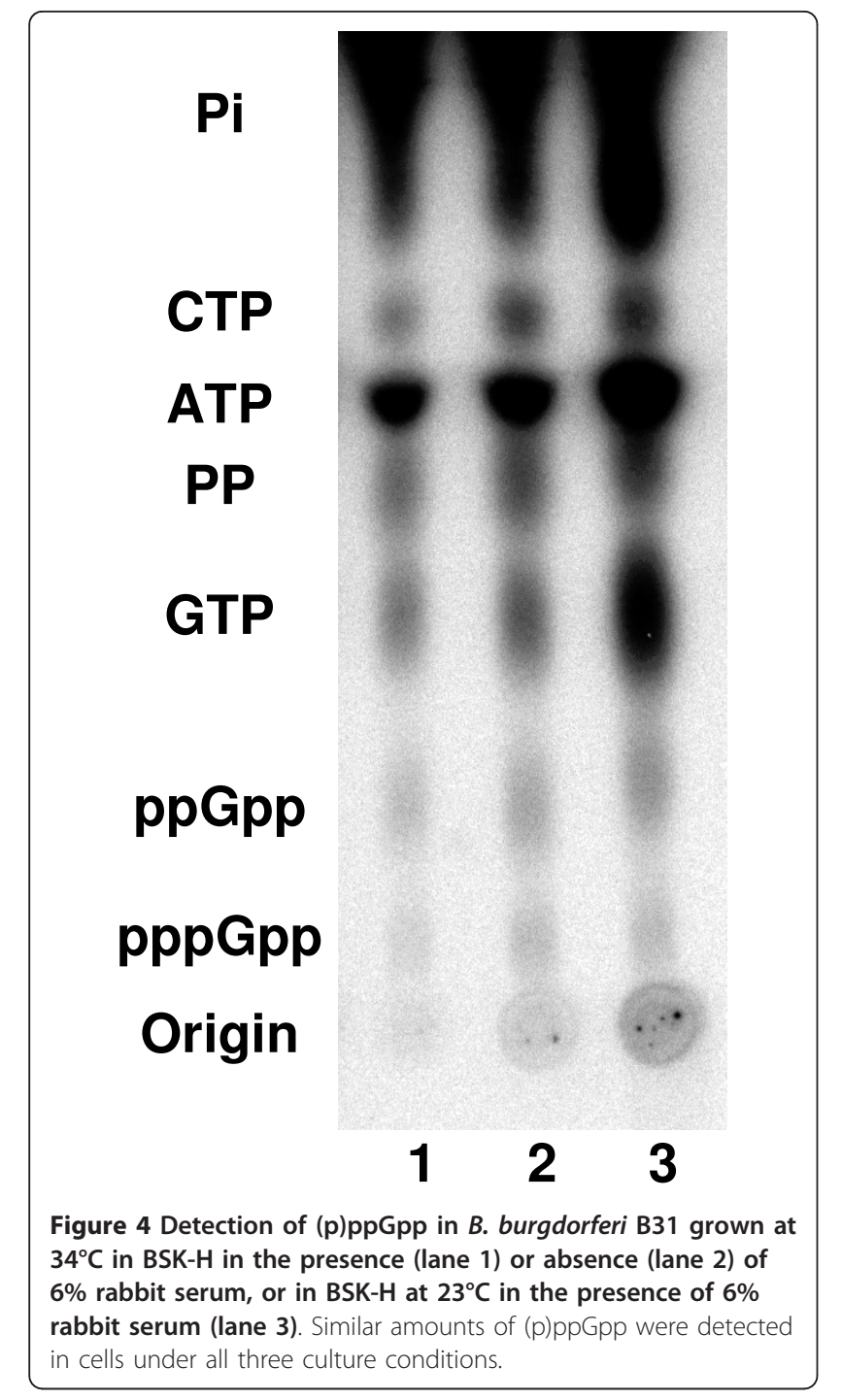

culture and decreased only slightly toward the end of the growth curve when the culture was reaching its maximum density and increased its doubling time (Figures $6 \mathrm{~B}, \mathrm{C})$. In contrast, rRNA levels in B. burgdorferi $\Delta$ rel $_{B b u}$ peaked at day five for both rRNA species, the first day of culture when cell densities of $\Delta r e l_{B b u}$ did not increase (Figure 6). The reverse correlation between cell division and rRNA accumulation in B. burgdorferi $\Delta \operatorname{rel}_{B b u}$ strongly suggests that $\mathrm{rel}_{B b u}$ is necessary for stringent control of rRNA synthesis in B. burgdorferi. This accumulation of rRNA is reminiscent of what occurs in the relaxed phenotype of $E$. coli relA mutants [9,24,25].

\section{Discussion}

We have demonstrated the existence of three different transcripts from the DNA region of B. burgdorferi coding for ribosomal RNA. One transcript contained $16 \mathrm{~S}$ rRNA and tRNA ${ }^{\text {Ala }}$, a second contained only tRNA ${ }^{\text {Ile }}$, and a third contained both sets of 23S-5S rRNA genes in tandem. These results confirm previous predictions that $B$. burgdorferi rRNA genes were not transcribed as a single unit $[15,16]$. B. burgdorferi is not the only spirochete in which rRNA genes are not organized into operons containing 16S-23S-5S genes in tandem [26]. The B. garinii genome encodes one copy of $16 \mathrm{~S}$ and two copies each of $23 \mathrm{~S}$ and $5 \mathrm{~S}$ rRNA genes organized similarly to those of $B$. burgdorferi [27], while B. japonica IKA2 has only a single copy of the 23S-5S rRNA gene [28]. Other spirochetes also have a limited number of rRNA genes which are often not organized in operons containing 16S-23S-5S genes in tandem. An early report indicated that the spirochete Leptospira interrogans had two copies of $16 \mathrm{~S}$ and single copies of $5 \mathrm{~S}$ and $23 \mathrm{~S}$ rRNA genes located far from each other and most probably not

\section{A. 16S rRNA}

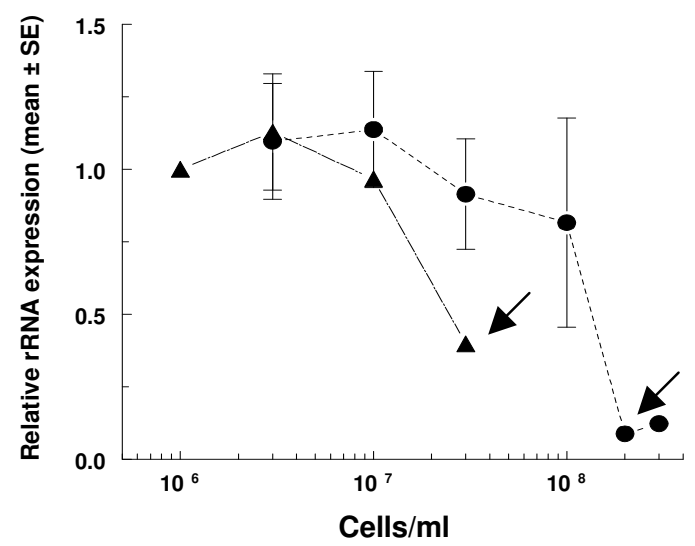

\section{B. 23S rRNA}

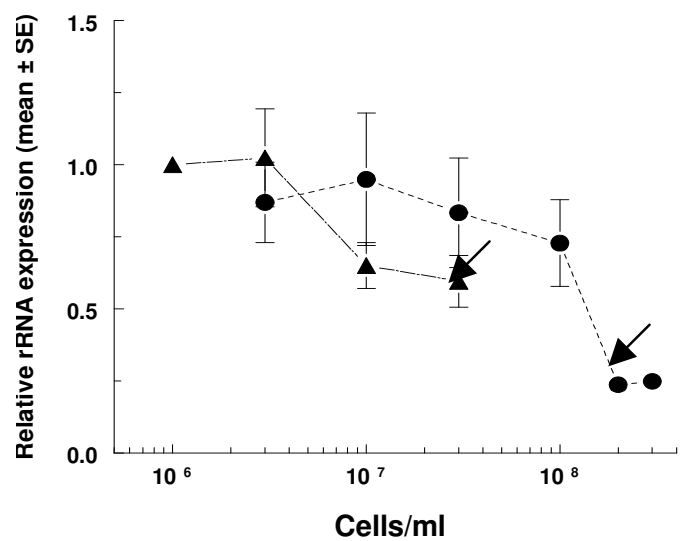

Figure 5 Expression of $16 \mathrm{~S}$ and $23 \mathrm{~S}$ rRNA (mean $\pm \mathrm{SE}$ ) normalized to flaB mRNA in B. burgdorferi B31 grown in complete BSK-H at $34^{\circ}$ $\mathrm{C}$ (solid circle) or at $23^{\circ} \mathrm{C}$ (triangle). Data are presented relative to normalized rRNA expression in $10^{6} \mathrm{cells} / \mathrm{ml}$ of $B$. burgdorferi grown at $23^{\circ} \mathrm{C}$ in complete BSK-H for each rRNA species separately. See Materials and Methods for details. Arrows indicate the onset of stationary phase. 


\section{A. Cell growth}

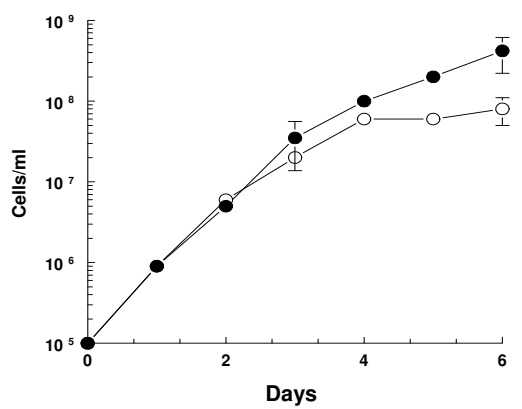

B. 16S rRNA

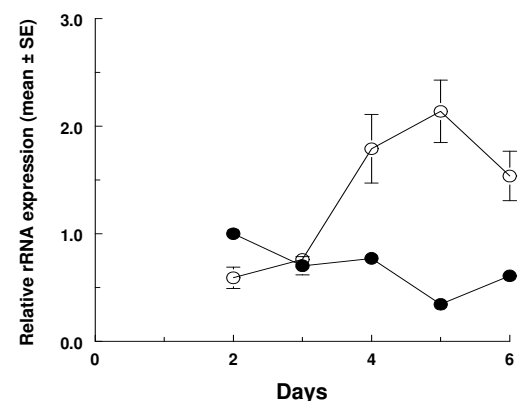

C. 235 rRNA

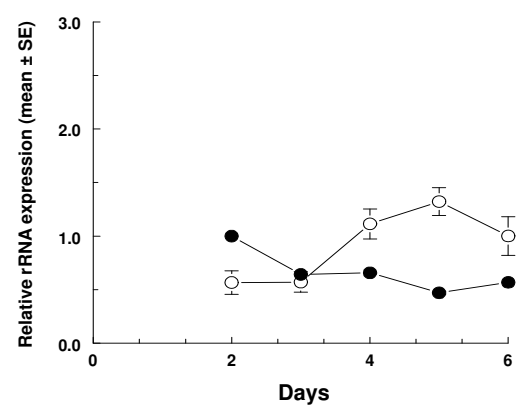

Figure 6 Cell growth (A) and expression of 16S (B) and $23 \mathrm{~S}$ (C) rRNA (mean \pm SE) normalized to flaB mRNA in wild-type (solid circle) and $\Delta$ rel $_{B b u}$ (open circle) B. burgdorferi 297 grown in complete BSK-H at $34^{\circ} \mathrm{C}$. Data are presented relative to normalized rRNA expression at day two of wild-type cell culture as described in Materials and Methods.

expressed together [29]. More recent whole genome sequencing has shown that the number of rRNA genes differs between two L. interrogans serovars. L. interrogans sv. Copenhageni has two copies of 23S, two copies of $16 \mathrm{~S}$, and one copy of $5 \mathrm{~S}$ rRNA genes, while L. interrogans sv. Lai has one copy of $23 \mathrm{~S}$ rRNA, two copies of $16 \mathrm{~S}$ rRNA, and one copy of $5 \mathrm{~S}$ rRNA genes [30,31]. The rRNA genes of both $L$. interrogans serovars are physically separated from each other and do not appear to form operons. However, not every spirochetal genome codes for individual rRNA genes that are not organized into operons. Treponema pallidum and T. denticola have two operons each coding for one copy of $16 \mathrm{~S}, 23 \mathrm{~S}$ and $5 \mathrm{~S}$ rRNA $[32,33]$. This variation in copy number and location of rRNA genes suggests that rRNA synthesis is controlled differently in different spirochetes.

It has been assumed that the presence of multiple copies of transcriptional units of rRNA in the order $16 \mathrm{~S}$, 23S and 5S rRNA facilitates the adaptation of bacteria to conditions that rapidly change their growth rate because they permit rapid changes in ribosomal synthesis $[11,14,26]$. In $E$. coli, sequential deletion of rRNA genes is accompanied by a decrease in the ability of the mutants to accelerate their growth rate under changing media conditions [34]. The location of rRNA genes close to the origin of replication in E. coli insures parallelism between replication and rRNA gene transcription and results in their high gene dosage in rapidly replicating cells [34]. That slow-growing bacteria such as spirochetes, mycoplasma and mycobacteria have a reduced number of rRNA gene copies could be intuitively related to a decreased adaptability resulting from their low numbers of rRNA copies and to a lack of coordinate transcription of the three RNA populations and DNA replication $[35,36]$. We have previously shown that inactivation of one of the 23S RNA genes in B. burgdorferi does not have any apparent effect on its adaptability to different growth conditions [37]. Moreover, a similar experiment has been performed in nature because B. japonica strain IKA2 lacks a second copy of the 23S5S rRNA gene cluster without any apparent adverse effects [28]. This suggests that B. burgdorferi has already adapted its growth rate to that permitted by its reduced number of rRNA genes. It thus appears that ascertainment of the biological role of differences in rRNA gene copy number in various bacterial species will require an extensive comparative analysis of the adaptability of bacteria with high and low numbers of rRNA genes to different growth conditions before any clear cut conclusions can be drawn.

Two major mechanisms regulating rRNA synthesis in E. coli are growth rate and the stringent response $[9,11]$. Our efforts to determine if B. burgdorferi rRNA synthesis was controlled by growth rate at a single temperature have been repeatedly frustrated by the still undefined nutritional requirements of B. burgdorferi and the lack of simple culture media for this organism $[38,39]$. We previously reported that (p)ppGpp levels in $B$. burgdorferi grown in BSK did not vary despite 10-fold reductions of yeastolate, neopeptone or rabbit serum [18]. We have now found that complete omission of rabbit serum from BSK-H did not affect growth of B. burgdorferi $\mathrm{B} 31$ at $34^{\circ} \mathrm{C}$ (Figure 3) or (p)ppGpp levels at $34^{\circ} \mathrm{C}$ or $23^{\circ} \mathrm{C}$ (Figure 4). It was thus not possible to alter $B$. burgdorferi growth rate at a given temperature by changing the composition of its culture medium $[11,40]$.

The slower growth of B. burgdorferi $\mathrm{B} 31$ at $23^{\circ} \mathrm{C}$ compared to $34^{\circ} \mathrm{C}$ correlated well with slower accumulation of total DNA, RNA and protein. Although there was a lag in cell number, total DNA and total protein in cells grown at the lower temperature, the amounts of DNA and protein per cell were similar at both temperatures. As expected, the amount of DNA per rapidly dividing exponential phase cells was higher than in more slowly 
dividing stationary phase cells. The slower rate of increase in total RNA in stationary phase cultures at the lower temperature also resulted in a significant difference in RNA per cell under these two conditions. Although these results were in agreement with the hypothesis that growth rate regulates rRNA synthesis in B. burgdorferi, further investigation determined that growth phase and not growth rate regulated rRNA levels under these conditions (Figure 5). Importantly, even though $B$. burgdorferi was grown for up to 11 days in $34^{\circ} \mathrm{C}$ culture and for 28 days in $23^{\circ} \mathrm{C}$ culture in our experiments, about $80 \%$ of all cells at this stationary phase stage are viable (R. Iyer and I. Schwartz, unpublished results), and non-viability cannot therefore account for the large decrease in rRNA levels in stationary phase in these cultures.

Amounts of $16 \mathrm{~S}$ and $23 \mathrm{~S}$ rRNA that were first normalized to mRNA amounts for constitutively expressed flaB and then additionally normalized to levels at $23^{\circ} \mathrm{C}$ and $10^{6}$ cells $/ \mathrm{ml}$ were similar in rapidly growing $\left(34^{\circ} \mathrm{C}\right)$ and slowly growing $\left(23^{\circ} \mathrm{C}\right)$ cultures when compared at the same growth phase; both RNA species decreased as the cultures progressed toward stationary phase (Figure 5). Production of constant levels of rRNA in exponentially growing $B$. burgdorferi that were independent of bacterial doubling time and the down-regulation of rRNA during stationary phase is similar to results obtained with Salmonella enterica sv. Typhimurium cultured in the same medium at different temperatures [40]. While cellular contents of DNA, RNA, and protein in cultures of $S$. Typhimurium grown in media of different nutritional content at a given temperature depended on growth rate, DNA, RNA, and protein per cell were nearly constant in cultures grown in the same medium at different temperatures and did not depend on growth rate [40].

We have previously shown that (p)ppGpp is necessary for the transition between exponential and stationary phase in B. burgdorferi [19], suggesting that rRNA synthesis may not be totally independent of (p)ppGpp, and that rRNA levels may be determined by interplay between two factors in this organism, growth phase and (p)ppGpp levels. In the present study, we found that both $B$. burgdorferi rRNA operons were misregulated in the absence of (p)ppGpp, and failed to down-regulate $16 \mathrm{~S}$ and $23 \mathrm{~S}$ rRNA levels during the transition to the stationary phase. Although our previous experiments with tick cell cultures suggested that growth-related mechanisms other than (p)ppGpp modulated rRNA synthesis in B. burgdorferi $[17,18]$, it is evident that the stringent response is also important for regulation of rRNA synthesis.

The mechanism by which (p)ppGpp regulates rRNA synthesis in B. burgdorferi during the transition phase and what other factors might be involved in this regulation is not yet clear. The accumulation of rRNA in B. burgdorferi $\Delta$ rel $_{B b u}$ suggests that this mutant behaves similarly to a relaxed phenotype relA mutant of E. coli (Figures 6B, C) $[9,24,25]$. This unbalanced growth may be responsible for the lack of cell division of the B. burgdorferi $\triangle$ rel $_{B b u}$ mutant in the stationary phase of growth (Figure 6A). B. burgdorferi has no homolog to the transcription factor DksA that acts as a cofactor in the repression of rRNA genes by (p)ppGpp in E. coli $[10,41,42]$. Even though B. burgdorferi codes for a homolog to the GTP-binding protein gene cgtA (BB0781) [10], this GTPase regulates (p)ppGpp levels only during exponential growth and does not have an effect during the stringent response [43]. Although not fully characterized, the role of the stringent response in the regulation of rRNA levels during stationary phase might have an effect on the ability of B. burgdorferi to survive in flat ticks or persist in animals. This might be accomplished perhaps by slowing down protein synthesis and conserving resources until nutritional conditions improve [44-46].

\section{Conclusions}

We have confirmed the prediction that B. burgdorferi rRNA genes are transcribed into three separate transcripts. We have also found that differences in expression of the rRNA operons associated with $B$. burgdorferi growth at different temperatures is regulated by growth phase rather than by growth rate, and that $r e l_{B b u}$ and its product (p)ppGpp is required for this regulation. These findings suggest that this bacterium has mechanisms for coordinated regulation of rRNA gene synthesis perhaps in response to metabolic changes triggered by entry into the stationary phase. Identification of these mechanisms is likely to be relevant to understanding the ability of B. burgdorferi to persist in the tick vector and the mammalian host.

\section{Methods}

\section{Bacterial strains and growth conditions}

Infectious, low-passage B. burgdorferi $\mathrm{N} 40$ was provided by Dr. L. Bockenstedt (Yale University, New Haven, CT). Non-infectious high-passage B. burgdorferi B31 was provided by Dr. J. Radolf (University of Connecticut Health Center, Farmington, CT). B. burgdorferi 297 (clone BbAH130) was provided by Dr. M. Norgard (University of Texas Southwestern Medical Center, Dallas, TX). This infectious wild-type strain was the parental strain for the $\Delta \operatorname{rel}_{B b u}$ B. burgdorferi [19]. B. burgdorferi strains were maintained at $34^{\circ} \mathrm{C}$ in BSK-H (Sigma Chemical Co., St. Louis, MO) supplemented with $6 \%$ rabbit serum (Sigma) (complete BSK-H) if not otherwise stated. Cell numbers were determined by dark-field microscopy as previously described [17]. 


\section{DNA isolation and PCR}

DNA from B. burgdorferi was isolated using High Pure PCR Template Preparation Kit (Roche Diagnostics Corporation, Indianapolis, IN). PCR amplification was performed using Taq DNA polymerase (Sibgene, Derwood, MD). Primers used for PCR are listed in Table 1. PCR was performed in a final volume of $10 \mu \mathrm{l}$ using an Idaho Technology RapidCycler (Idaho Technology Inc., Salt Lake City, UT). The amplification program consisted of denaturation at $94^{\circ} \mathrm{C}$ for $15 \mathrm{sec}$; followed by 37 cycles of $94^{\circ} \mathrm{C}$ for $10 \mathrm{sec}-53^{\circ} \mathrm{C}$ for $10 \mathrm{sec}-72^{\circ} \mathrm{C}$ for $50 \mathrm{sec}$ (for tRNA $^{\text {Ala }}{ }_{\text {-tRNA }}{ }^{\text {Ile }}$ region) or for 2 min (for tRNA ${ }^{\text {Ile }}$-23S rRNA region); and final extension at $72^{\circ} \mathrm{C}$ for $30 \mathrm{sec}$.

\section{RNA isolation and RT-PCR}

RNA from B. burgdorferi was isolated with TRIzol Reagent (Invitrogen Life technology, Carlsbad, CA.) according to the manufacturer's recommendations and was treated with RQ1 RNase-free DNase (Promega Corporation, Madison, WI) to eliminate DNA contamination. Primers used for RT-PCR are listed in Table 1 and their location shown in Figure 1. RT-PCR was performed using the Access RT-PCR system (Promega) in the RapidCycler using the following conditions: reverse transcription at $48^{\circ} \mathrm{C}$ for $45 \mathrm{~min}$, denaturation at $94^{\circ} \mathrm{C}$ for $2 \mathrm{~min}$; followed by 35 cycles of $94^{\circ} \mathrm{C}$ for $10 \mathrm{sec}-52^{\circ} \mathrm{C}$ (5S rRNA, tRNA ${ }^{\text {Ile }}$, tRNA $^{\text {Ala }}$, tRNA ${ }^{\text {Ala }}$ - tRNA ${ }^{\text {Ile }}$, tRNA $^{\text {Ile }}$ 23S rRNA, 23S rRNA - 5S rRNA and 5S rRNA - 23S rRNA intergenic regions) or $56^{\circ} \mathrm{C}$ (16S rRNA, 23S rRNA and 16S rRNA-tRNA ${ }^{\text {Ala }}$ intergenic region) for $10 \mathrm{sec}-68^{\circ} \mathrm{C}$ for $50 \mathrm{sec}$ (all rRNA and tRNA genes and their intergenic regions except tRNA ${ }^{\text {Ile }}$-23S rRNA and 23S rRNA- 5S rRNA intergenic regions) or for 2 min (tRNA ${ }^{\text {Ile }}$-23S rRNA and $23 \mathrm{~S}$ rRNA-5S rRNA intergenic regions); and final extension at $68^{\circ} \mathrm{C}$ for $5 \mathrm{~min}$.

\section{Isolation and measurement of total DNA and total RNA}

B. burgdorferi B31 were grown from $3 \times 10^{4}$ cells $/ \mathrm{ml}$ in BSK-H with or without $6 \%$ rabbit serum at $34^{\circ} \mathrm{C}$, or in BSK-H with $6 \%$ of rabbit serum at $23^{\circ} \mathrm{C}$. B. burgdorferi from $50-70 \mathrm{ml}$ cultures were collected by centrifugation, washed twice with PBS, pH 7.5, resuspended in $900 \mu \mathrm{l}$ of PBS and mixed with $100 \mu \mathrm{l}$ of $50 \%$ trichloroacetic acid at $0^{\circ} \mathrm{C}$. After at least $15 \mathrm{~min}$ at $0^{\circ} \mathrm{C}$, the cells were collected on glass fiber filters without binders (Millipore, Ireland, $25 \mathrm{~mm}$ diameter, $2.7 \mu \mathrm{m}$ particle penetration) and washed with $20 \mathrm{ml}$ of $5 \%$ trichloroacetic acid. Filters containing the entrapped cells were folded, placed in the bottom of a test tube $(13 \times 100 \mathrm{~mm})$ and covered with $2 \mathrm{ml}$ of $5 \%$ trichloroacetic acid. The tubes were capped and placed in a $90^{\circ}-95^{\circ} \mathrm{C}$ water bath for $20 \mathrm{~min}$. After cooling, glass filters were sedimented by centrifugation and DNA and RNA concentrations were determined colorimetrically on aliquots of the supernatant fluid by diphenylamine (for DNA) or orcinol (for RNA) assays $[22,23]$. Each experiment was repeated twice with two technical replicates. Data are presented as means $\pm \mathrm{SE}$.

\section{Measurement of total protein}

B. burgdorferi B31 were grown as above. B. burgdorferi cells from $1.5 \mathrm{ml}$ cultures were collected by centrifugation, washed twice with PBS, $\mathrm{pH} 7.5$, to remove any adherent proteins derived from the culture medium, resuspended in $50 \mu \mathrm{l}$ of lysis buffer containing $50 \mathrm{mM}$ Tris- $\mathrm{HCl}, \mathrm{pH} 7.5 ; 0.15 \mathrm{M} \mathrm{NaCl} 1 \mathrm{mM}$ EDTA; 0.1\% Triton X-100 and incubated on ice for 10 minutes. Total protein was measured using the Bradford method [47] (Bio-Rad Protein Assay, Bio-Rad Laboratories) with a bovine serum albumin standard. Each experiment was repeated twice with two technical replicates. Data are presented as means $\pm \mathrm{SE}$.

\section{Detection of (p)ppGpp}

(p)ppGpp was extracted from $\left[{ }^{32} \mathrm{P}\right]$-labeled B. burgdorferi and chromatographed on cellulose PEI-TLC plates (Selecto Scientific, Suwanee, GA) as previously described [17]. Plates were air-dried, exposed to phosphor screen (Molecular Dynamics, Sunnyvale, CA) for 12 to $24 \mathrm{~h}$ and scanned using a Storm 860 PhosphorImager (Molecular Dynamics).

\section{Reverse transcription and Real-time PCR}

cDNA synthesis was performed with $1 \mu \mathrm{g}$ of total B. burgdorferi RNA using random primers $\mathrm{p}(\mathrm{dN})_{6}$ (Roche) and avian myeloblastosis virus reverse transcriptase (Promega) according to the manufacturer's recommendations. To quantify flaB mRNA and $16 \mathrm{~S}$ and $23 \mathrm{~S}$ rRNA, the resulting cDNAs were amplified and analyzed on a LightCycler Real-time PCR instrument (Roche) using LightCycler Master SYBR Green I Mixture (Roche). PCR was performed in glass capillaries in a final volume of $20 \mu \mathrm{l}$ as previously described [18]. The amplification program consisted of denaturation at $95^{\circ} \mathrm{C}$ for $2 \mathrm{~min}$; followed by 35 cycles of $95^{\circ} \mathrm{C}$ for $1 \mathrm{~s}-55^{\circ}$ $\mathrm{C}$ (flaB and $23 \mathrm{~S}$ rRNA) or $57^{\circ} \mathrm{C}$ (16S rRNA) for $5 \mathrm{~s}-72^{\circ}$ $\mathrm{C}$ for $10 \mathrm{~s}$. PCR reactions were performed at least twice for each RNA isolate. RNA isolated from at least two independent cultures was used for experiments with temperature change. PCR reactions were performed 4 times for each RNA isolate in experiments with $\mathrm{rel}_{B b u}$ mutant, and RNA was isolated from one culture for days 2,4 and 5, and from two independent cultures for days 3 and 6 . Results using two different primer sets for 16S rRNA quantification (Table 1, Figure 1) were similar and were therefore combined. Genomic DNA from $10^{3}-10^{6}$ cells of the corresponding $B$. burgdorferi strain was used as a standard to estimate the amount of cDNA for genes studied in each Real-time PCR. Samples 
were normalized to the amount of cDNA of constitutively expressed flaB. Relative rRNA expression levels (copies rRNA/copies flaB) were computed for each individual rRNA species (16S or $23 \mathrm{~S}$ rRNA). Because flaB mRNA expression is constitutive $[48,49]$, and flaB is located on the chromosome distal to the origin of replication [50] which ensures that there is only one copy of $f l a B /$ borrelial cell, normalization with $f l a B$ is adequate. In RT RT-PCR experiments with different temperature, these expression levels were further normalized to expression during growth in $\mathrm{BSK}-\mathrm{H}$ at $23^{\circ} \mathrm{C}$ and $10^{6}$ cells $/ \mathrm{ml}$. In experiments with $\Delta r \mathrm{rel}_{B b u}$, the expression levels were normalized to expression of wild-type at day two - the first day when RNA was collected, separately for $16 \mathrm{~S}$ and $23 \mathrm{~S}$ rRNA. Relative rRNA expression of each rRNA species is presented as mean $\pm \mathrm{SE}$.

\section{Statistical methods}

Differences in mean levels of rRNA transcription, cell numbers and amounts of total DNA, RNA and protein were statistically analyzed using a one-way analysis of variance with a Tukey-Kramer multiple comparisons post-test. Differences were deemed significant if $\mathrm{P}<0.05$.

\section{List of Abbreviations}

BSK: Barbour-Stoenner-Kelly; cDNA: DNA complementary to RNA; PCR: polymerase chain reaction; (p)ppGpp: (guanosine-3'-dipyrophosphate-5'triphosphate and guanosine-3', ' $^{\prime}$-bispyrophosphate, collectively); rRNA: ribosomal RNA; tRNA: transfer RNA.

\section{Acknowledgements}

We thank Drs. Romilio Espejo and Dionysios Liveris for advice and discussions, Drs. Guiqing Wang and Caroline Ojaimi for help with Real-time PCR, Dr. Linda Bockenstedt for providing B. burgdorferi N40, Dr. Justin Radolf for providing B. burgdorferi B31, and Dr. Michael Norgard for providing B. burgdorferi 297. This work was supported by NIH grant Al 48856 to F. C. Cabello.

\section{Author details}

'Department of Microbiology and Immunology, Basic Science Building, New York Medical College, Valhalla, NY 10595, USA. ²Department of Pathology, Basic Science Building, New York Medical College, Valhalla, NY 10595, USA.

\section{Authors' contributions}

JVB carried out the molecular genetic and growth studies and drafted the manuscript. HPG performed the statistical analysis, participated in the coordination of the study and helped draft the manuscript. IS participated in the design of the study and helped draft the manuscript. FCC conceived of the study, participated in its design and coordination and helped draft the manuscript. All authors read and approved the final manuscript.

\section{Authors' information}

JVB is currently at the Department of Microbiology and Immunology, Emory University School of Medicine, 1510 Clifton road, Atlanta, GA 30322, USA. HPG is currently at the Department of Pathology, Basic Science Building, New York Medical College, Valhalla, NY 10595, USA. IS and FCC are currently at the Department of Microbiology and Immunology, Basic Science Building, New York Medical College, Valhalla, NY 10595, USA.

Received: 19 September 2010 Accepted: 20 January 2011 Published: 20 January 2011
References

1. Steere AC, Coburn J, Glickstein L: The emergence of Lyme disease. J Clin Invest 2004, 113:1093-1101.

2. Tilly K, Rosa PA, Stewart PE: Biology of infection with Borrelia burgdorferi. Infect Dis Clin North Am 2008, 22:217-234.

3. de Silva AM, Fikrig E: Growth and migration of Borrelia burgdorferi in Ixodes ticks during blood feeding. Am J Trop Med Hyg 1995, 53:397-404.

4. Schwan TG, Piesman J, Golde WT, Dolan MC, Rosa PA: Induction of an outer surface protein on Borrelia burgdorferi during tick feeding. Proc Natl Acad Sci USA 1995, 92:2909-2913.

5. Stevenson B, Schwan TG, Rosa PA: Temperature-related differential expression of antigens in the Lyme diseaase spirochete, Borrelia burgdorferi. Infect Immun 1995, 63:4535-4539.

6. Yang X, Goldberg MS, Popova TG, Schoeler GB, Wikel SK, Hagman KE, et al: Interdependence of environmental factors influencing reciprocal patterns of gene expression in virulent Borrelia burgdorferi. Mol Microbiol 2000, 37:1470-1479.

7. Revel AT, Talaat AM, Norgard MV: DNA microarray analysis of differential gene expression in Borrelia burgdorferi, the Lyme disease spirochete. Proc Natl Acad Sci USA 2002, 99:1562-1567.

8. Bremer H, Dennis PP: Modulation of chemical composition and other parameters of the cell by growth rate. In Escherichia coli and Salmonella: Cellular and Molecular Biology. Volume 2. 2 edition. Edited by: Neidhardt FC, Curtiss R, III, Ingraham JL, Lin ECC, Low KB, Magasanik B. Washington, D.C.: ASM Press; 1996:1553-1569.

9. Cashel M, Gentry DR, Hernandez VJ, Vinella D: The stringent response. In Escherichia coli and Salmonella: Cellular and Molecular Biology. Volume 1. 2 edition. Edited by: Neidhardt FC, Curtiss R, III, Ingraham JL, Lin ECC, Low KB, Magasanik B et al. Washington, DC: ASM Press; 1996:1458-1496.

10. Fraser CM, Casjens S, Huang WM, Sutton GG, Clayton R, Lathigra R, et al: Genomic sequence of a Lyme disease spirochaete, Borrelia burgdorferi. Nature 1997, 390:580-586.

11. Keener J, Nomura M: Regulation of ribosomal synthesis. In Escherichia coli and Salmonella: Cellular and Molecular Biology. Volume 1. 2 edition. Edited by: Neidhardt FC, Curtiss R, III, Ingraham JL, Lin ECC, Low KB, Magasanik B. Washington, D.C.: ASM Press; 1996:1417-1431.

12. Karpinets TV, Greenwood DJ, Sams CE, Ammons JT: RNA:protein ratio of the unicellular organism as a characteristic of phosphorous and nitrogen stoichiometry and of the cellular requirement of ribosomes for protein synthesis. BMC Biol 2006, 4:30.

13. Schneider DA, Gourse RL: Changes in Escherichia coli rRNA promoter activity correlate with changes in initiating nucleoside triphosphate and guanosine 5'-diphosphate-3'-diphosphate concentrations after induction of feedback control of ribosome synthesis. J Bacteriol 2003, 185:6185-6191.

14. Paul BJ, Barker MM, Ross W, Schneider DA, Webb C, Foster JW, et al: DksA: a critical component of the transcription initiation machinery that potentiates the regulation of rRNA promoters by ppGpp and the initiating NTP. Cell 2004, 118:311-322.

15. Schwartz JJ, Gazumyan A, Schwartz I: rRNA gene organization in the Lyme disease spirochete, Borrelia burgdorferi. J Bacteriol 1992, 174:3757-3765.

16. Gazumyan A, Schwartz JJ, Liveris D, Schwartz I: Sequence analysis of the ribosomal RNA operon of the Lyme disease spirochete, Borrelia burgdorferi. Gene 1994, 146:57-65.

17. Bugrysheva J, Dobrikova EY, Godfrey HP, Sartakova ML, Cabello FC: Modulation of Borrelia burgdorferi stringent response and gene expression during extracellular growth with tick cells. Infect Immun 2002, 70:3061-3067.

18. Bugrysheva J, Dobrikova EY, Sartakova ML, Caimano MJ, Daniels TJ, Radolf JD, et al: Characterization of the stringent response and rel ${ }_{B b u}$ expression in Borrelia burgdorferi. J Bacteriol 2003, 185:957-965.

19. Bugrysheva J, Bryksin AV, Godfrey HP, Cabello FC: Borrelia burgdorferi rel is responsible for generation of guanosine-3'-diphosphate-5'-triphosphate and growth control. Infect Immun 2005, 73:4972-4981.

20. Anderson JF: Ecology of Lyme disease. Conn Med 1989, 53:343-346.

21. Anguita J, Hedrick MN, Fikrig E: Adaptation of Borrelia burgdorferi in the tick and the mammalian host. FEMS Microbiol Rev 2003, 27:493-504.

22. Volkin E, Cohn WE: Estimation of nucleic acids. Methods Biochem Anal 1954, 1:287-305, 287-305.

23. Lazzarini RA, Cashel M, Gallant J: On the regulation of guanosine tetraphosphate levels in stringent and relaxed strains of Escherichia coli. J Biol Chem 1971, 246:4381-4385. 
24. Borek E, Rockenbach J, Ryan A: Studies on a mutant of Escherichia coli with unbalanced ribonucleic acid synthesis. J Bacterio/ 1956, 71:318-323.

25. Atherly AG: Temperature-sensitive relaxed phenotype in a stringent strain of Escherichia coli. J Bacteriol 1973, 113:178-182

26. Schneider DA, Ross W, Gourse RL: Control of rRNA expression in Escherichia coli. Curr Opin Microbiol 2003, 6:151-156.

27. Glöckner G, Lehmann R, Romualdi A, Pradella S, Schulte-Spechtel U, Schilhabel $M$, et al: Comparative analysis of the Borrelia garinii genome. Nucleic Acids Res 2004, 32:6038-6046.

28. Marconi RT, Liveris D, Schwartz I: Identification of novel insertion elements, restriction fragment length polymorphism patterns, and discontinuous $23 \mathrm{~S}$ rRNA in Lyme disease spirochetes: phylogenetic analyses of rRNA genes and their intergenic spacers in Borrelia japonica sp. nov. and genomic group 21038 (Borrelia andersonii sp. nov.) isolates. J Clin Microbiol 1995, 33:2427-2434.

29. Fukunaga M, Mifuchi I: Unique organization of Leptospira interrogans rRNA genes. J Bacteriol 1989, 171:5763-5767

30. Ren $S X$, Fu G, Jiang XG, Zeng $R$, Miao $Y G$, Xu H, et al: Unique physiological and pathogenic features of Leptospira interrogans revealed by wholegenome sequencing. Nature 2003, 422:888-893.

31. Nascimento ALTO, Ko Al, Martins EAL, Monteiro-Vitorello CB, Ho PL, Haake DA, et al: Comparative genomics of two Leptospira interrogans serovars reveals novel insights into physiology and pathogenesis. J Bacteriol 2004, 186:2164-2172.

32. Fraser CM, Norris SJ, Weinstock GM, White O, Sutton GG, Dodson R, et al: Complete genome sequence of Treponema pallidum, the syphilis spirochete. Science 1998, 281:375-388.

33. Seshadri R, Myers GS, Tettelin H, Eisen JA, Heidelberg JF, Dodson RJ, et al: Comparison of the genome of the oral pathogen Treponema denticola with other spirochete genomes. Proc Natl Acad Sci USA 2004, 101:5646-5651.

34. Condon C, Liveris D, Squires C, Schwartz I, Squires CL: rRNA operon multiplicity in Escherichia coli and the physiological implications of $r \mathrm{rn}$ inactivation. J Bacteriol 1995, 177:4152-4156.

35. Stemke GW, Huang Y, Laigret F, Bove JM: Cloning the ribosomal RNA operons of Mycoplasma flocculare and comparison with those of Mycoplasma hyopneumoniae. Microbiology 1994, 140(Pt 4):857-860.

36. Gonzalez-y-Merchand JA, Garcia MJ, Gonzalez-Rico S, Colston MJ, Cox RA: Strategies used by pathogenic and nonpathogenic mycobacteria to synthesize rRNA. J Bacteriol 1997, 179:6949-6958.

37. Morozova OV, Dubytska LP, Ivanova LB, Moreno CX, Bryksin AV, Sartakova ML, et al: Genetic and physiological characterization of $23 \mathrm{~S}$ rRNA and ftsJ mutants of Borrelia burgdorferi isolated by mariner transposition. Gene 2005, 357:63-72

38. Yang X, Popova TG, Goldberg MS, Norgard MV: Influence of cultivation media on genetic regulatory patterns in Borrelia burgdorferi. Infect Immun 2001, 69:4159-4163.

39. Wang G, lyer R, Bittker S, Cooper D, Small J, Wormser GP, et al: Variations in Barbour-Stoenner-Kelly culture medium modulate infectivity and pathogenicity of Borrelia burgdorferi clinical isolates. Infect Immun 2004, 72:6702-6706

40. Schaechter M, Maaløe O, Kjeldgaard NO: Dependency on medium and temperature of cell size and chemical composition during balanced grown of Salmonella typhimurium. J Gen Microbiol 1958, 19:592-606.

41. Paul BJ, Berkmen MB, Gourse RL: DksA potentiates direct activation of amino acid promoters by ppGpp. Proc Natl Acad Sci USA 2005 102:7823-7828.

42. Srivatsan A, Wang JD: Control of bacterial transcription, translation and replication by (p)ppGpp. Curr Opin Microbiol 2008, 11:100-105.

43. Jiang M, Sullivan SM, Wout PK, Maddock JR: G-protein control of the ribosome-associated stress response protein SpoT. J Bacteriol 2007, 189:6140-6147

44. Braeken K, Moris M, Daniels R, Vanderleyden J, Michiels J: New horizons for (p)ppGpp in bacterial and plant physiology. Trends Microbiol 2006 14:45-54.

45. Potrykus K, Cashel M: (p)ppGpp: still magical? Annu Rev Microbiol 2008 , 62:35-51, 35-51.

46. Sureka K, Ghosh B, Dasgupta A, Basu J, Kundu M, Bose I: Positive feedback and noise activate the stringent response regulator rel in mycobacteria. PLOS ONE 2008, 3:e1771.
47. Bradford MM: A rapid and sensitive method for the quantitation of microgram quantities of protein utilizing the principle of protein-dye binding. Anal Biochem 1976, 72:248-254.

48. de Silva AM, Zeidner NS, Zhang Y, Dolan MC, Piesman J, Fikrig E: Influence of outer surface protein A antibody on Borrelia burgdorferi within feeding ticks. Infect Immun 1999, 67:30-35.

49. Hodzic E, Feng S, Freet KJ, Barthold SW: Borrelia burgdorferi population dynamics and prototype gene expression during infection of immunocompetent and immunodeficient mice. Infect Immun 2003, 71:5042-5055.

50. Picardeau M, Lobry JR, Hinnebusch BJ: Physical mapping of an origin of bidirectional replication at the centre of the Borrelia burgdorferi linear chromosome. Mol Microbiol 1999, 32:437-445.

doi:10.1186/1471-2180-11-17

Cite this article as: Bugrysheva et al:: Patterns and regulation of ribosomal RNA transcription in Borrelia burgdorferi. BMC Microbiology 2011 11:17

\section{Submit your next manuscript to BioMed Central and take full advantage of:}

- Convenient online submission

- Thorough peer review

- No space constraints or color figure charges

- Immediate publication on acceptance

- Inclusion in PubMed, CAS, Scopus and Google Scholar

- Research which is freely available for redistribution

Submit your manuscript at www.biomedcentral.com/submit
C Biomed Central 